\title{
ROLE OF NATURAL FACTORS AND HUMAN ACTIVITIES IN LAND DEGRADATION OF THE MEGHALAYA PLATEAU (NORTHEAST INDIA)
}

DOI: http://dx.doi.org/10.18509/GBP.2020.18

UDC: 502.521:504]:551.3(540)

\author{
Pawel Prokop \\ Department of Geoenvironmental Research, Institute of Geography and Spatial Organization, \\ Polish Academy of Sciences, Jana 22, 31-018 Kraków, Poland
}

\begin{abstract}
The southern slope of the Meghalaya Plateau located in the Northeast India, separated on several spurs by deep canyons, receives the highest rainfall at global scale. Former human activity, in the extreme monsoonal rainfall conditions reaching $11,000 \mathrm{~mm}$ annually, facilitated soil degradation and expansion of grasslands at the expense of forest at higher elevated spurs. The paper attempts to determine the relative importance of human activities as compared to natural processes in land degradation of the southern slope of the Meghalaya Plateau. The spur area of $70 \mathrm{~km}^{2}$ near Cherrapunji was selected for detailed study. Rainfall data from Cherrapunji station, satellite image from Google Earth, soil survey and census data were used for estimation of role of different factors in land degradation. Visual analysis of satellite image derived from Google Earth indicated dominance of grasslands (73\%) with small contribution of forest (18\%), built up area $(6 \%)$ and surface mining of limestone and coal (2\%) in land use structure. Cultivated area occupied less than $1 \%$ of the study area. Impoverished soil, high annual rainfall together with annual burning of vegetation and grazing are the most probable causes of present day stability of grasslands within Cherrapunji spur. Soil erosion under degraded grasslands is now similar to that observed in natural forests and does not reflect the impact of high rainfall energy. Despite deforestation and severe soil degradation, the population has increased over the past few decades. This increase was associated with the intensification of coal and limestone extraction as well as the simultaneous development of tourism.
\end{abstract}

Keywords: high rainfall, land use, runoff, soil erosion, population

\section{INTRODUCTION}

Land degradation is a complex concept that describes how natural resources are depleted or their quality deteriorates [1]. Degradation is a social problem, regardless of whether degradation processes occur with or without human interference, because it limits the current or potential land use [2]. The problem of degradation is not limited to developing countries, areas with high population density or a specific morphoclimatic zone. However, there are environments that are inherently more susceptible to degradation, e.g. mountains with steep slopes receiving very high rainfall, seismically active areas or regions affected by prolonged drought and subjected to intensive human activities [3].

The Meghalaya Plateau is one of the rainiest inhabited environments on Earth, with more than $11,000 \mathrm{~mm}$ of precipitation recorded annually in Cherrapunji. Although plateau has sufficient precipitation and temperature to support forest growth, grasses growing on degraded soils prevail at elevations of above $1000 \mathrm{~m}$ a.s.l. [4], [5]. As a result, in the landscape of the Meghalaya coexist elements of the processes characteristic for 
monsoonal as well as steppe environment [6]. At the same time, the climax vegetation of the sacred groves (forest patches protected through the ages by the local people) is the evidence that the plateau must have been covered by forest in the past [7].

The presented paper attempts to determine the relative importance of human activities as compared to natural processes in land degradation of the southern slope of the Meghalaya Plateau.

\section{MATERIALS AND METHODS}

\section{Study area}

The southern slope of the Meghalaya Plateau located in the Northeast India is separated on several spurs by deep canyons [8] (Figure 1). The spur area of $70 \mathrm{~km}^{2}$ near Cherrapunji (1300 $\mathrm{m}$ a.s.1.) was selected for detailed study. The mean monthly temperature in Cherrapunji fluctuates between $11.6^{\circ} \mathrm{C}$ in winter (January) and $20.6^{\circ} \mathrm{C}$ in summer (August). The lifting of the southerly monsoon airflow causes water vapor condensation and high annual rainfall of 11,000 $\mathrm{mm}$ [9]. Horizontally bedded sandstones with the thick limestone beds are parent materials for Inceptisols and Ultisols [10]. Majority of the soils covering an area of about $80 \%$ area is loamy sand and sandy loam. They fall under stony and rocky classes at the surface level [11]. Landscape is hilly with short but relatively steep slopes (up to $40^{\circ}$ ) [12]. The study area is mostly deforested and overgrown with grasses. The population density doubled since 1981 and reached 320 inhabitants $\mathrm{km}^{-2}$ in 2011 [13]. About 50\% of the population lives in Cherrapunji, the only city. In contrast to the whole Meghalaya State, most of the population is employed outside the agricultural sector, mainly in mineral extraction, tourism and trade.

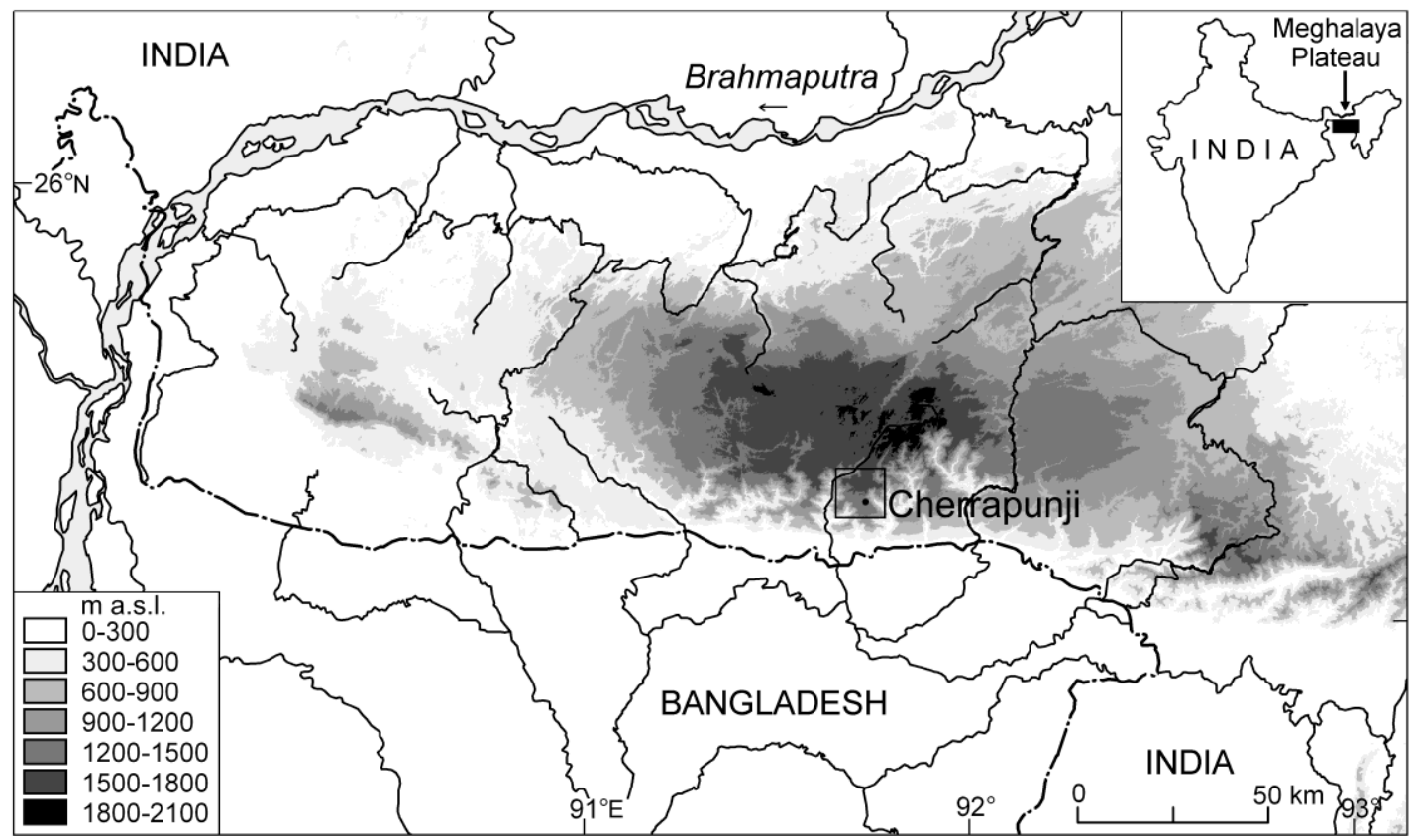

Figure 1: Location of the Cherrapunji spur in the Meghalaya Plateau

\section{Data analyses}

The rainfall records for Cherrapunji have been collected from Regional Meteorological Office in Guwahati. The detailed rainfall structure has been analysed on the basis of daily rainfall for 2000 year, when rainfall totals were close to long-term average. Rainfall 
erosivity has been calculated from hyetographs using Universal Soil Loss Equation (USLE) rules for the same year [14]. Additionally there were calculated erosive rains in accordance with recommendations for tropical areas [15]. The method assumes that only rainfalls of the above $25 \mathrm{~mm} \cdot \mathrm{h}^{-1}$ have a sufficient intensity to initiate the soil erosion.

The land use land cover (LULC) of the study area was prepared on the basis of Google Earth satellite image at spatial resolution of $0.5 \mathrm{~m}$ from 2018 digitised at scale of 1:5,000 and verified during field survey. Five LULC classes were delimited: forest, grasses, agriculture, built up and surface mineral extraction. The land use was supplemented by soil physico-chemical features inventory on the basis of soil map and field survey at a scale 1:50,000 [11].

\section{RESULTS AND DISCUSSION}

\section{Impact of rainfall}

The most distinctive feature of the Cherrapunji spur is the large amount of rain that annually falls in this area (Table 1). The intensity of rain expressed in millimetres per time unit controls the start and rate of runoff following soil erosion and therefore is one of the basic parameters used in formulas describing the soil erosion. Detailed studies on the basis of the four years (1999-2002) of measurements in Cherrapunji using of the pluviometer with 1-second time resolution show that rainfall intensities generally do not exceed 1.0-1.5 mm min ${ }^{-1}$, and highest are close to $2.0 \mathrm{~mm} \mathrm{~min}^{-1}$ [6]. Observations were confirmed by the analysis of hyetographs in 15 and 30-minutes intervals for 2000 year. The highest rainfall during 15 minutes reached $53 \mathrm{~mm}$ (e.g. $3.5 \mathrm{~mm} \mathrm{~min}^{-1}$ ).

Table 1: Characteristic of rainfall in Cherrapunji in 2000

\begin{tabular}{|l|r|}
\hline Rainfall parameters & Rainfall amount and number \\
\hline Amount of annual rainfall $(\mathrm{mm})$ & 12,255 \\
\hline Amount of annual erosive rainfall (mm) (USLE rules) & 10,043 \\
\hline Number o rainy days & 180 \\
\hline Number o rainy days $>100 \mathrm{~mm}$ & 42 \\
\hline Number of erosive rains (USLE rules) & 132 \\
\hline Number of rains $>25 \mathrm{~mm} \cdot \mathrm{h}^{-1}$ in $15 \mathrm{~min}$. & 457 \\
\hline
\end{tabular}

Rainfall erosivity supplements rainfall characteristic from the initiations of soil erosion. Calculations based on hyetographs have shown that erosive rains reach $80 \%$ of total rainfall and are observed every month in Cherrapunji. The number of erosive rains of the above $25 \mathrm{~mm} \cdot \mathrm{h}^{-1}$ was almost four times higher than calculated using USLE rules.

\section{Impact of human activities on LULC}

There are evidences from historical accounts of British naturalist that grasslands around Cherrapunji had existed before the $19^{\text {th }}$ century [16], [17]. They have paid attention on iron industry developed in this part of Khasi Hills from immemorial times. The cutting trees which have been used for charcoal production necessary for smelting iron ore was the major cause of deforestation and land degradation around Cherrapunji [18]. Due to a long duration human activity with successive periods of land clearing and abandonment, most of the primary subtropical forests have been converted to grasses.

The analysis of satellite image derived from Google Earth indicated dominance of grasslands $(73 \%)$ with small contribution of forest (18\%), built up area (6\%) and surface mining of limestone and coal (2\%) in the present-day land use structure (Figure 2). Forest preserved only in the deep incised valleys or protected areas. The succession with tree 
species was prevented by annual practice of grass fires and grazing [19]. The built-up areas increased with the increase in the population. The expansion of built up areas occurred mainly at the expense of grasslands. Many of the new buildings constitute the hotel base for the dynamically developing tourism in the last 10 years. Surface coal and limestone extraction also contributed to LULC. Most of such activities were located within the already degraded grasslands [20]. Land degraded due to coal extraction was largest in extent. Coal extraction involved removing of vegetation in an area of about 200$300 \mathrm{~m}$ radius and digging a pit few meters below ground till the coal seam. Removal of grass cover with gravel surface led to exposure of subsurface layers of soil to heavy rainfall and acceleration of the erosion process. Both physical and chemical soil properties even 20 years after mining operation were not able to return to pre-mined level [20]. The agriculture was scarce and limited mainly to home gardens due to the degraded soil and high rainfall. Cultivated fields occupied less than $1 \%$ of the spur.

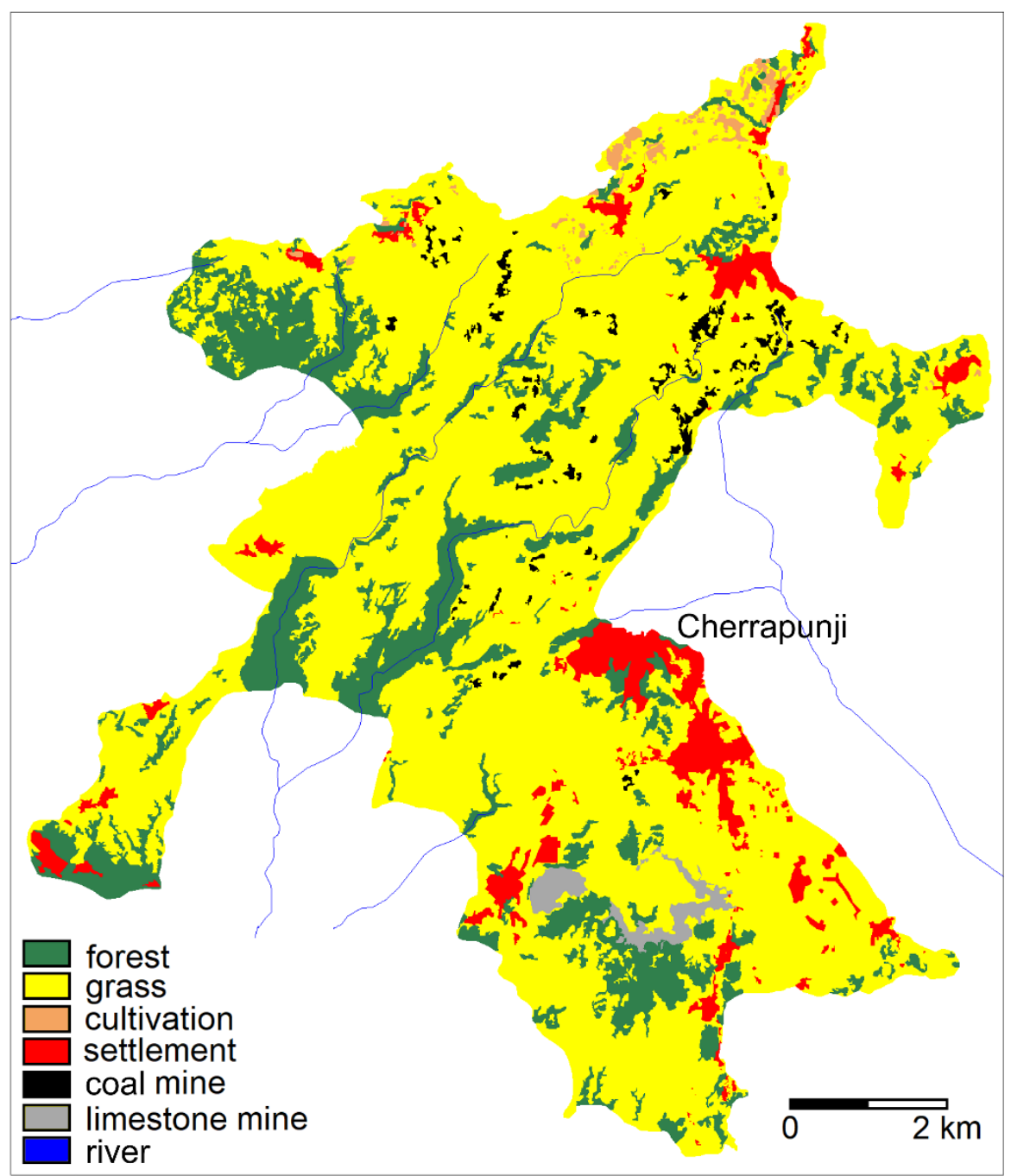

Figure 2: LULC of Cherrapunji spur in 2018. White area indicates canyons.

\section{Impact of natural factors and human activities on soil erosion}

High rainfall and hilly topography of the Cherrapunji spur create potential conditions for efficient runoff and soil erosion. These natural processes can be greatly accelerated by human activities. Typical soil erosion rates under natural forest are usually below few $\mathrm{t}$ 
$\mathrm{ha}^{-1} \mathrm{yr}^{-1}$ and depend mainly on rainfall, topography, soil properties and vegetation [15]. Intensity of soil erosion can be significantly increased through clearing of the natural vegetation.

Thus, present-day land degradation is connected with deforestation of natural evergreen forest in historical times as well as shallow soils developed on resistant to weathering sedimentary rocks [21], [22]. Removal of vegetation accelerated soil erosion and caused the formation on the degraded surface either as an armoured layer pavement built of coarse rock fragments and iron concretions or even the exposure of bedrock (Table 2). As a result, only a small part of the former regolith has still been preserved [6], [22].

Table 2: Selected physico-chemical properties of topsoil developed on sandstones within Cherrapunji spur

\begin{tabular}{|c|l|l|l|l|l|l|r|r|}
\hline \multirow{2}{*}{ LULC } & \multirow{2}{*}{$\begin{array}{l}\text { Soil } \\
\text { horizon }\end{array}$} & $\begin{array}{l}\text { Depth } \\
(\mathbf{c m})\end{array}$ & $\begin{array}{l}\text { Skeleton } \\
\mathbf{2 . 0} \\
(\mathbf{m m})\end{array}$ & $\begin{array}{l}\text { Sand } \\
\mathbf{2 . 0 - 0 . 0 5} \\
(\mathbf{m m})\end{array}$ & $\begin{array}{l}\text { Silt } \\
\mathbf{0 . 0 5 - 0 . 0 0 2} \\
(\mathbf{m m})\end{array}$ & $\begin{array}{l}\text { Clay } \\
\mathbf{< 0 . 0 0 2} \\
(\mathbf{m m})\end{array}$ & pH & $\begin{array}{l}\text { Organic } \\
\text { matter } \\
(\boldsymbol{\%})\end{array}$ \\
\hline Forest & ABbr & $0-15$ & 1.6 & 55.3 & 24.9 & 19.8 & 4.3 & 5.3 \\
\hline Grass & ABbr & $0-15$ & 65.3 & 77.5 & 18.1 & 4.4 & 4.5 & 3.6 \\
\hline
\end{tabular}

Estimation of soil loss under the degraded grasslands using 137Cs radionuclide tracer has shown that medium term erosion rates are only $2.1 \mathrm{t} \mathrm{ha}^{-1} \mathrm{yr}^{-1}$ in Cherrapunji spur [23]. The small contribution of fine soil particles in A horizon, very dense grass root system typical for steppe areas [24] and thick layer of stone pavement protects well subsurface layers against erosion. Low erosion indicates that compact pavement of soil and root grass system has exerted a greater control over the sediment transfer than the energy impact of the rainfall and runoff. Impermeable surface horizon reduces the infiltration rate and facilitates high runoff (69-81\% of annual rainfall) which depends also on the frequency of grass burning and development of biomass [24]. The runoff is significantly reduced to $27 \%$ of annual rainfall under remnants of natural forest near Cherrapunji [25]. The surface of soil under forest is protected against erosion by thick detrital layer associated with fine roots of trees and ground vegetation.

\section{CONCLUSIONS}

Deforestation and progressive erosion in the past have caused soil degradation that led to a permanent change in the structure of LULC on the southern slope of a hilly plateau near Cherrapunji. As a result, erosion under degraded grasslands is now similar to that observed in natural forests and does not reflect the impact of high rainfall energy. Impoverished soil, high annual rainfall together with annual burning of vegetation and grazing are the most probable causes of present day stability of grasslands within Cherrapunji spur. These operated for long time causes play key role in preserving degraded land inherited from the past. Despite deforestation and severe soil degradation, the population has increased over the past few decades. This increase was associated with the intensification of coal and limestone extraction as well as the simultaneous development of tourism.

\section{Acknowledgments}

This paper was completed as a part of the cooperation between Polish Academy of Sciences, Warsaw, and Indian National Science Academy, New Delhi. 


\section{REFERENCES}

[1] Eswaran H., Lal R., Reich P.F. Land degradation: an overview. Science Publishers, Inc., Enfield, NH, USA, pp 20-35, 2001.

[2] Blaikie P., Brookfield H. Land degradation and society. Methuen, London, UK, 1987.

[3] Barrow C.J. Land Degradation: Development and breakdown of terrestrial environments. Cambridge University Press, UK, 1991.

[4] Rączkowska Z., Bucała-Hrabia A., Prokop P. Geomorphological and sedimentological indicators of land degradation (Meghalaya Plateau, NE India). Land Degradation \& Development, vol. 29, pp 2746-2759, 2018.

[5] Prokop P., Kruczkowska B., Syiemlieh H.J., Bucała-Hrabia A. Impact of topography and sedentary swidden cultivation on soils in the hilly uplands of North-East India. Land Degradation \& Development, vol. 29, pp 2760-2770, 2018.

[6] Starkel L., Singh S. (Eds.). Rainfall, runoff and soil erosion in the globally extreme humid area, Cherrapunji region, India. Prace Geograficzne IGiPZ PAN, 191, Poland, 2004.

[7] Bor N.L. Relict vegetation of Shillong Plateau-Assam. Indian Forest Records, vol. 3, pp 152195, 1942.

[8] Prokop P. The Meghalaya Plateau: Landscapes in the abode of the clouds. Springer, Dordrecht, Germany, pp 173-180, 2014.

[9] Prokop P., Walanus A. Variation in the orographic extreme rain events over the Meghalaya Hills in northeast India in the two halves of the twentieth century. Theoretical and Applied Climatology, vol. 121, pp 389-399, 2015.

[10] Soil Survey Staff. Keys to soil taxonomy. Washington DC, USDA, USA, 2014.

[11] Nair K.M., Kumar K.S., Mukherjee S., Utpal Baruah. Land use planning of Cherrapunji, Meghalaya (Soil resource assessment), National Bureau of Soil Survey and Land Use Planning, Nagpur, Department of Soil Conservation, Government of Meghalaya, Shillong, India, 2005.

[12] Migoń P., Prokop P. Landforms and landscape evolution in the Mylliem granite area, Meghalaya Plateau, Northeast India. Singapore Journal of Tropical Geography, vol. 34, pp 206228, 2013.

[13] Government of India. Census of India 2011. New Delhi, Government of India, 2011.

[14] Wischmeier W.H., Smith D.D. Predicting rainfall erosion losses. USDA Agricultural Research Service Handbook, 537, Washington, USA 1978.

[15] Hudson N.W. Soil Conservation. Batsford, London, UK, 1982.

[16] Walters H. Journey across the Pandua Hills, near Silhet, in Bengal. Asiatic Researches, vol. 17, pp 499-512, 1832.

[17] Pemberton R.B. Report on the Eastern Frontier of British India. Government of India, Calcutta, 1835.

[18] Prokop P., Suliga I. Two thousand years of iron smelting in the Khasi Hills, Meghalaya, North East India. Current Science, vol. 104, pp 761-768, 2013.

[19] Ramakrishnan P.S., Ram S.C. Vegetation, biomass and productivity of seral grasslands at Cherrapunji in North-East India. Vegetatio, vol. 84, pp 47-53, 1988.

[20] Shankar U., Boral L., Pandey H.N., Tripathi R.S. Degradation of land due to coal mining and its natural recovery pattern. Current Science, vol. 65, pp 680-687, 1993.

[21] Ramakrishnan P.S. Shifting agriculture and sustainable development: An interdisciplinary study from North-Eastern India. Parthenon Publications, Carnforth, UK, 1992. 
[22] Prokop P., Bhattacharyya A. Reconnaissance of quaternary sediments from Khasi Hills, Meghalaya. Journal of the Geological Society of India, vol. 78, pp 258-262, 2011.

[23] Froehlich W. Soil erosion, suspended sediment sources and deposition in the Maw-Ki-Syiem drainage basin, Cherrapunji, northeastern India. IAHS Publication, 288, pp 138-146, 2004.

[24] Ram S.C., Ramakrishnan P.S. Litter production and decomposition patterns in seral grasslands at Cherrapunji in north-eastern India. Pedobiologia, vol. 32, pp 65-76, 1988.

[25] Khiewtam R.S. Ecosystem function of protected forests of Cherrapunji and adjoining areas. $\mathrm{PhD}$ Thesis, North-Eastern Hill University, Shillong, India, 1986. 